\title{
Problems and Countermeasures of Innovation and Entrepreneurship Education in Agricultural Colleges and Universities
}

\author{
Yuci Wang \\ Beijing University of Agriculture \\ Beijing, 102206, China
}

\begin{abstract}
There are some problems in innovation and entrepreneurship education in agricultural colleges and universities, such as lack of understanding on the concept of innovation and entrepreneurship education, lack of innovation and entrepreneurship education in general education, lack of deep integration of professional education and so on. In view of the problems existing in innovation and entrepreneurship education in agricultural colleges and universities, this work put forward some countermeasures for carrying out innovation and entrepreneurship education in agricultural colleges and universities, such as strengthening the consciousness of innovation and entrepreneurship, optimizing the curriculum system of innovation and entrepreneurship education, strengthening the construction of teaching staff of innovation and entrepreneurship education, establishing the long-term mechanism of innovation and entrepreneurship education and so on, so as to provide reference for innovation and entrepreneurship education in agricultural colleges and universities.
\end{abstract}

Keywords-Agricultural Colleges and Universities; Innovation and Entrepreneurship Education; Problems; Countermeasures

\section{INTRODUCTION}

General Secretary Xi Jinping pointed out in The Report of The 19th CPC National Congress that it is necessary to speed up building an innovative country. Innovation has become the first driving force leading economic development. Deepening the reform of innovation and entrepreneurship education is a new requirement for colleges and universities to upgrade the industrial structure of economic development in China. In recent years, the State Council and the Ministry of Education have issued a number of programmatic documents for innovation and entrepreneurship education, which has defined the direction for colleges and universities to carry out innovation and entrepreneurship education. As an agricultural college with distinctive characteristics, it undertook the task of providing intellectual support and talent support for the development of agricultural modernization. Strengthening innovation and entrepreneurship education and improving students' awareness and ability of innovation and entrepreneurship in agricultural colleges and universities is the inevitable requirement to promote the development and transformation and upgrading of agricultural modernization and it is also an urgent need for the country to implement the strategy of innovation-driven development.

\section{THE PROBLEMS EXISTING IN THE EDUCATION OF INNOVATION AND ENTREPRENEURSHIP IN AGRICULTURAL COLLEGES AND UNIVERSITIES.}

\section{A. Lack of understanding of the educational concept of innovation and entrepreneurship}

Due to the lack of in-depth thinking about teaching reform and the lack of understanding of the concept of innovation and entrepreneurship education for a long time, some agricultural colleges and universities, especially the connotation and training mode of innovative talents, have not formed a systematic theoretical system. In the process of personnel training, some colleges and universities attach importance to theory, and lack the training of students' innovative ability and practical ability. The main means of cultivating innovative talents is to open several elective courses of innovation courses and hold or participate in innovation and entrepreneurship competitions. Only in the face of some students with interest in innovation and entrepreneurship without facing all students, innovative education can't be integrated into professional education, and there is a gap with the needs of innovative and entrepreneurial talents needed by the state and society. Innovative and entrepreneurial talent is a new requirement for the cultivation of talents in colleges and universities in the new period of economic development and scientific and technological progress. It is a multi-level and different type of talent characterized by "innovation", which integrates basic knowledge, professional skills and innovative ability. It is the need of building innovative national development strategy to attach importance to the cultivation of students' innovative consciousness, innovative thinking and innovative ability in the process of application [1].

\section{B. Innovation and entrepreneurship education, general education, and the deep integration of professional education is not enough}

Some colleges and universities do not run through the whole process of innovation and entrepreneurship education, and most of them are short-term training for students before graduation, rather than systematically imparting innovative and entrepreneurial knowledge and skills to students. The innovative and entrepreneurial courses are lack of systematicness, and most of them are scattered in the elective 
courses of general education, which does not reflect the professional advantages and characteristic with small quantity. Thus, this can't meet the needs of students. In the process of professional education, only pay attention to the indoctrination of professional knowledge; do not pass on the concept of innovation and entrepreneurship to students. The compulsory courses are not attached importance to, while the number of elective courses is small. Moreover, the innovation and entrepreneurship education and the subject professional education are not well integrated, and the students' knowledge is narrow, which can't meet the needs of the development of modern agriculture [2].

\section{Lack of teachers in innovative and entrepreneurial education}

Innovation and entrepreneurship education involves multidisciplinary knowledge, which requires teachers to have not only the professional knowledge of related industries, but also the knowledge and ability of innovation and entrepreneurship. It is necessary to combine economics, management, law and other professional knowledge. However, the innovation and entrepreneurship education in colleges and universities in China starts late, lacking special disciplines and specialties, and the teachers of innovation and entrepreneurship education are seriously lacking. Some agricultural colleges and universities are mainly conducted by counselors, class teachers and employment guidance teachers in student offices. These teachers lack innovative entrepreneurial knowledge and ideas, lack practical ability and knowledge structure, and are not targeted and effective, which can't meet the needs of cultivating such talents.

\section{The guarantee system of innovation and entrepreneurship education is not perfect}

Although some schools have made some achievements in the training of innovative entrepreneurial talents, they are not perfect enough in ensuring the training and implementation of innovative entrepreneurial talents. Some colleges and universities are still in the stage of propaganda and encouragement for innovation and entrepreneurship, and in the aspects of teacher training, curriculum construction, incentive measures, rules and regulations, financial support and management, etc., which is not systematic and perfect and restricts the training of innovative entrepreneurial talents in agricultural colleges and universities [3]

\section{ANALYSIS ON THE COUNTERMEASURES OF THE INNOVATION AND ENTREPRENEURSHIP EDUCATION IN THE AGRICULTURAL COLLEGES AND UNIVERSITIES}

\section{A. Strengthen the consciousness of innovation and entrepreneurship and renew the concept of education}

Only by strengthening the consciousness of innovation and entrepreneurship education, forming the concept of innovation and entrepreneurship education among teachers and students and reaching a consensus, from teachers, students to teaching, management, environment and so on, can innovation and entrepreneurship education achieve practical results. Innovative education is an educational activity to cultivate students' innovative thinking, innovative consciousness, innovative ability and so on, paying attention to the cultivation of students' comprehensive quality. Entrepreneurship education is based on innovation education and promotes innovation education, which complement each other. Moreover, entrepreneurship education is an educational activity with entrepreneurial spirit, entrepreneurial consciousness and entrepreneurial basic quality, and mastering the basic skills of entrepreneurship. The goal of innovation education and entrepreneurship education is same, and more reasonable knowledge structure and ability structure are created for students from different levels and angles. According to the characteristics of agricultural subjects and students, agricultural colleges and universities should integrate innovation and entrepreneurship education into the whole process of talent training. In addition, we need to strengthen the concept of innovation and entrepreneurship education among teachers and students, and to write it into the school talent training objectives and annual work plan and to sum up the materials, so that the major meetings such as the school Congress and the teaching activities of all teachers and students could be integrated. The educational concept and the idea of running a school of innovation and entrepreneurship in agricultural colleges and universities have inherent unity. Thus, according to the actual needs of the construction of a new socialist countryside and the development of modern agriculture, we should train high-quality and innovative applied talents who are willing to serve agriculture, rural areas and farmers with modern agricultural scientific and technological knowledge.

B. Integrate general education, professional education and innovation and entrepreneurship education, and optimize the curriculum system of innovation and entrepreneurship education

1) Optimize the course system of innovation and entrepreneurship education

First, we should integrate the innovative start-up education into the system of general education and professional education, and face all the students to open the necessary courses and elective courses related to the innovation and start-up, such as the cultivation of innovative ability, the foundation of innovation and entrepreneurship, the design and planning of the start-up and the like. Second, we should set up cross-courses, such as creative agriculture, food innovation, and so on, combining with professional characteristics. The course not only pays attention to the integration of innovation and entrepreneurship education and professional education, but also pays attention to the combination with the specialty of the agricultural department, so as to realize the organic integration of the innovation and entrepreneurship education and the general education and the professional education. Through the establishment of basic courses of innovation and entrepreneurship education, professional courses of innovation and entrepreneurship education, practical courses of innovation and entrepreneurship education, and innovation and entrepreneurship incubation platform, we can improve the quality of courses. By integrating innovation and entrepreneurship education into general education and professional education, the goal of innovation and 
entrepreneurship education running through the whole process of talent training is realized.

2) Update teaching content, and supports teaching by scientific research

We should merge similar courses, promote the renewal of teaching contents, reorganize the curriculum structure, and encourage teachers to bring scientific research achievements and advanced technology into the classroom, into teaching materials, into theoretical teaching or experimental teaching content. To a certain extent, it can promote the professional courses to reflect the cutting-edge scientific and technological knowledge and scientific research achievements in a timely manner, and can also ensure that students master the most advanced scientific ideas and contents, and inspire and cultivate students' innovative thinking and ability. We should encourage teachers to bring undergraduates into their own scientific research projects and guide students to carry out scientific research. At the same time, we should encourage teachers to expand the scientific research base established by the scientific research team and the comprehensive experimental station of the industrial system. Further, we can build a student professional practice base, and cultivate students' scientific research innovation ability. Finally, we should actively open various laboratories to provide guarantee for students to complete scientific research training, innovation and entrepreneurship competition.

3) Integrate the whole practice teaching content, and optimize the innovation and the practice teaching system

In order to cultivate students' creative spirit and innovation ability with social and industrial needs, we need to integrate practical teaching content, add design experiments, comprehensive experiments, or experimental projects that embody advanced technology. Teachers are encouraged to integrate the latest scientific research achievements of the subject into the experimental teaching content, so that the experimental courses can reflect the cutting-edge of science and technology and research hotspots and can improve the students' creative thinking and the advancement of innovation ability. In another aspect, we ought to change the traditional teaching methods of experimental practice, optimize the teaching methods to cultivate the students' creative and entrepreneurship quality and practical ability, and bring classroom experiment, teaching practice, social practice, production practice, graduation practice, etc. Moreover, the overall arrangement is throughout the whole process of talent cultivation.

4) Construct a pluralistic practical teaching platform for cooperative education

First, through school-enterprise cooperation, we should build students' practical training and innovation and entrepreneurship platform. This can rely on the university science and technology park, with the help of entry enterprises to carry out innovation and entrepreneurship training and professional practice. The University Science and Technology Park of Beijing Agricultural College is composed of $100 \mathrm{mu}$ market, $1000 \mathrm{mu}$ farm and 10,000 mu forest farm, which provides a platform for students to carry out professional skills training, scientific research training and innovation and entrepreneurship training, attracts excellent entrepreneurial projects to enter the park and gives financial assistance, and promotes the improvement of students' practical ability and Innovation and entrepreneurship ability. Second, we should strengthen cooperation with off-campus talent training base to promote the improvement of students' comprehensive practical ability. Beijing Agricultural College should establish a joint training base with Shounong Group, Dabinong Group, Shunxin Agriculture and so on, so that students can combine theory and technology through practice and improve their ability to apply professional knowledge to practice. Third, we should cooperate with scientific research institutes to build a platform for scientific and technological innovation. Further, we should also select students with solid professional foundation, strong innovation consciousness and high scientific research literacy, practicing in scientific research institutes, receiving scientific research training and innovation ability training.

5) Perfect the education system of innovation and entrepreneurship with the help of the second classroom

First, based on student associations, we should strengthen the atmosphere of innovation and entrepreneurship. Through the establishment of innovation and entrepreneurship team, we should set up college students entrepreneurship park, customer space and other community organizations to provide a good platform for innovation and entrepreneurship for students in college and universities. Second, based on the subject competition, we should cultivate students' innovative and entrepreneurial quality and ability. Through certain policies, students are encouraged to participate in Challenge Cup, innovation and entrepreneurship competition, subject competition, scientific research training project and so on. According to the needs of different majors and grades, we should establish a student innovation platform to achieve the whole process, omni-directional, all-round scientific and technological innovation and education atmosphere. Third, we should build a social practice education system to improve students' innovative ability and practical ability. Moreover, we should combine the characteristics of the school and professional characteristics, carry out social practice activities, so that to let students apply professional knowledge to society in social practice and improve students' ability to solve practical problems.

\section{Strengthening the Construction of Teachers in Innovation and Entrepreneurship Education}

Innovative entrepreneurship education needs innovative teachers, and we require innovative teachers to train innovative students. According to the characteristics of the school and the situation of students, agricultural colleges and universities, on the one hand, let teachers "go out"; on the other hand, these schools bring teachers in and constantly strengthen the construction of teaching staff. First, we should strengthen the training of innovative and entrepreneurial teachers in schools, invite experts or models of innovation and entrepreneurship education in foreign schools, and give lectures and training to teachers. To provide a learning platform for innovative and entrepreneurial teachers, we should organize teachers to participate in academic 
discussions inside and outside the school. Qualified schools can provide teachers with the opportunity to exercise in enterprises, so that teachers can obtain the experience of innovation and entrepreneurship education through their own experience and practice, and improve their theoretical level and practical ability. In class, we should be more persuasive to students' education and improve the effect of classroom teaching [4]. Second, we should introduce a number of fulltime teachers with strong awareness of innovation and entrepreneurship, rich knowledge and strong ability, so as to improve the overall level of innovative and entrepreneurial teachers. Third, we should employ successful innovative entrepreneurs, well-known entrepreneurs, agricultural technology or management experts as part-time teachers outside the school, regularly or irregularly carry out Innovation and entrepreneurship education and training guidance for students, impart successful innovative entrepreneurial experience to students, advanced agricultural science and technology and so on, so as to guide students to carry out innovative and entrepreneurial practice. Moreover, we should strengthen the education and guidance of students and improve the level of innovation and entrepreneurship education in schools in an all-round way. Through in-school training, out-of-school introduction, full-time and part-time combination, we can form a high level of innovative and entrepreneurial teachers with reasonable professional title proportion structure.

\section{Strengthen System Management and Establish Long-term Mechanism of Innovation and Entrepreneurship Education}

We should carry out innovation and entrepreneurship education which requires the coordination, overall arrangement and joint promotion of all departments of the school. First, agricultural colleges and universities should give full play to the advisory and guiding role of innovation and entrepreneurship experts, set up the guidance center of innovation and entrepreneurship education, and realize the guidance of innovation and entrepreneurship education policy, realization path, training platform construction and innovation and entrepreneurship practice activities. This department is responsible for coordinating the work of various departments, guiding, supervising and checking all departments, so that all the work can be carried out and jointly promotes the education of innovation and entrepreneurship [5]. Second, we should perfect the management system of innovation and entrepreneurship education, reform the credit system of innovation and entrepreneurship, the course selection system and the evaluation system of teachers' professional titles, so as to provide institutional guarantee for the comprehensive development of innovation and entrepreneurship education. For example, By establishing the credit conversion system of innovation and entrepreneurship, we should convert the achievements of innovation and entrepreneurship and the results of competition awards into credits according to different grades. Only in this way, can we carry out material rewards and spiritual encouragement and improve the enthusiasm of students. Moreover, teachers should guide students to make achievements in subject competition or innovation, identify the workload, and regard it as an important basis for year-end assessment and professional title promotion.

\section{CONCLUSION}

Innovation and entrepreneurship education is a complex and arduous systematic innovation project, which involves all aspects of education and teaching. The development of Innovation and entrepreneurship education in agricultural colleges and universities is not only the need of higher education teaching reform under the new situation, but also the urgent requirement of agricultural modernization. Agricultural colleges and universities should rely on the professional characteristics of the school, strengthen the awareness of innovation and entrepreneurship among teachers and students and reach a consensus, optimize the curriculum system of innovation and entrepreneurship education, strengthen the construction of teachers of innovation and entrepreneurship education, and establish a long-term mechanism of innovation and entrepreneurship education. Only in this way can we realize the smooth development and achievement of innovation and entrepreneurship education, improve the students' innovative and entrepreneurial literacy as a whole, and train the high-quality innovative entrepreneurial agricultural talents needed by social development.

\section{REFERENCES}

[1] Feng Shide, Ji Yuxi, Sun Taifan. Ways And Exploration of Cultivating Applied Innovative Talents in Local Agricultural Colleges And Universities[J]. Contemporary Educational Practice and Teaching Research, 2019(1): 174-175

[2] Zhou Xu. Construction And Practice of Innovation And Entrepreneurship Education System in Local Agricultural Colleges and Universities[J]. Journal of Chizhou University, 2016, 30(5): 137-142.

[3] [Tian Jie, Shi Yun, Wu Yanyan, etc. Integrate Innovation And Entrepreneurship Education Into The Talent Training System of Loca Agricultural And Forestry Colleges and Universities[J]. Journal of Hebei Agricultural University (Agriculture and Forestry Education Edition), 2017, 19(4): 6-11

[4] Yao Chunyan, Li Na. Research on The Problems and Countermeasures of Innovation And Entrepreneurship Education in Colleges And Universities[J]. A Comparative Study of Cultural Innovation, 2019(2): 121-122.

[5] Cai Na, Zhang Jihe. Analysis on The Present Situation And Countermeasures of Innovation And Entrepreneurship Education for Agricultural College Students[J]. Guide to Science and Education, 2016(15): 175-177. 